*alls View/Frint Document Cover Sheet tose

This document was retrieved from the Boeing ISEARCH System.

Accession \#: D196069804

Document \#: SD-WM-TP-275

Title/Desc:

TANK 241BY108 TANK CHARACTERIZATION PLAN 


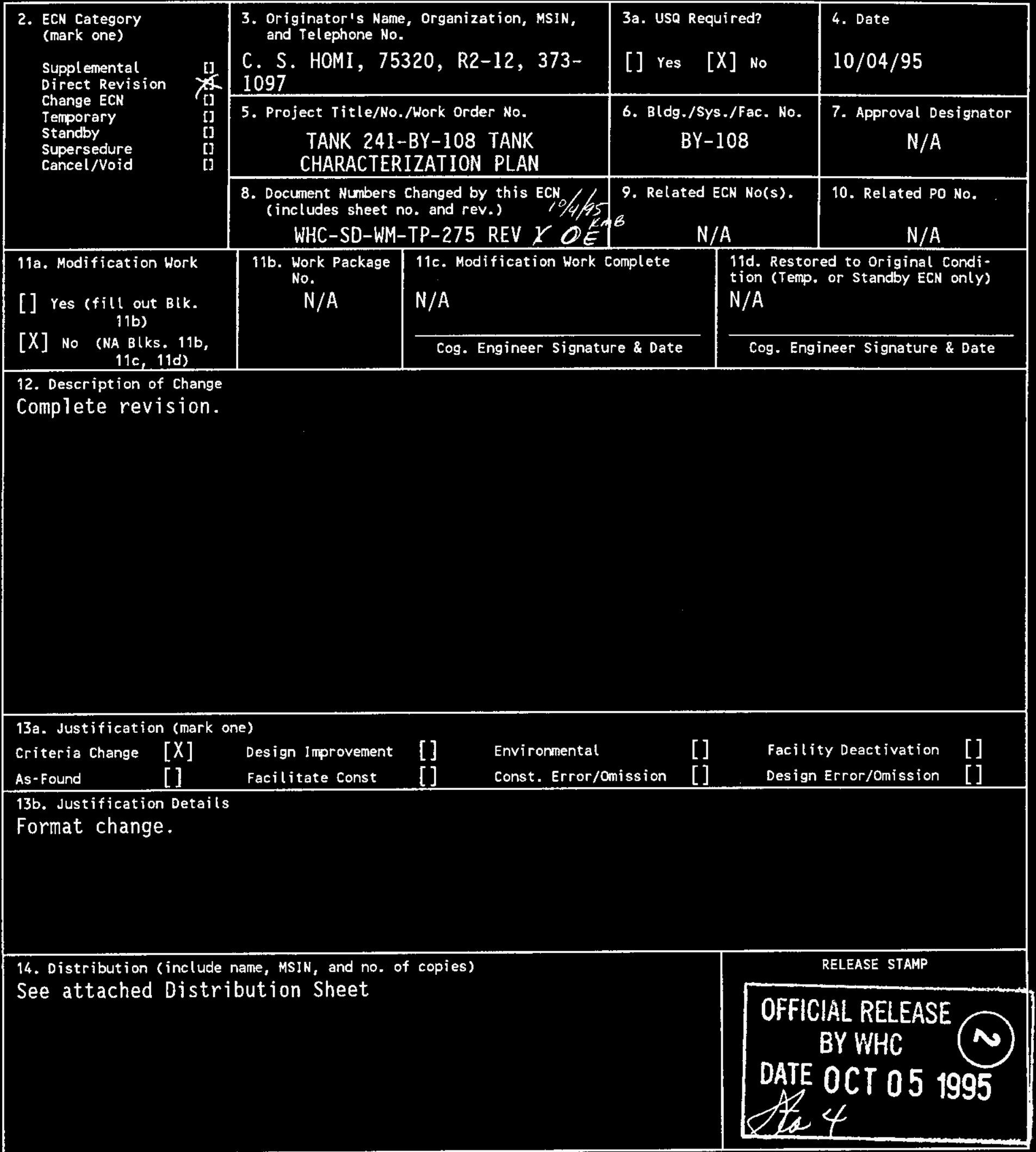


ENGINEERING CHANGE NOTICE

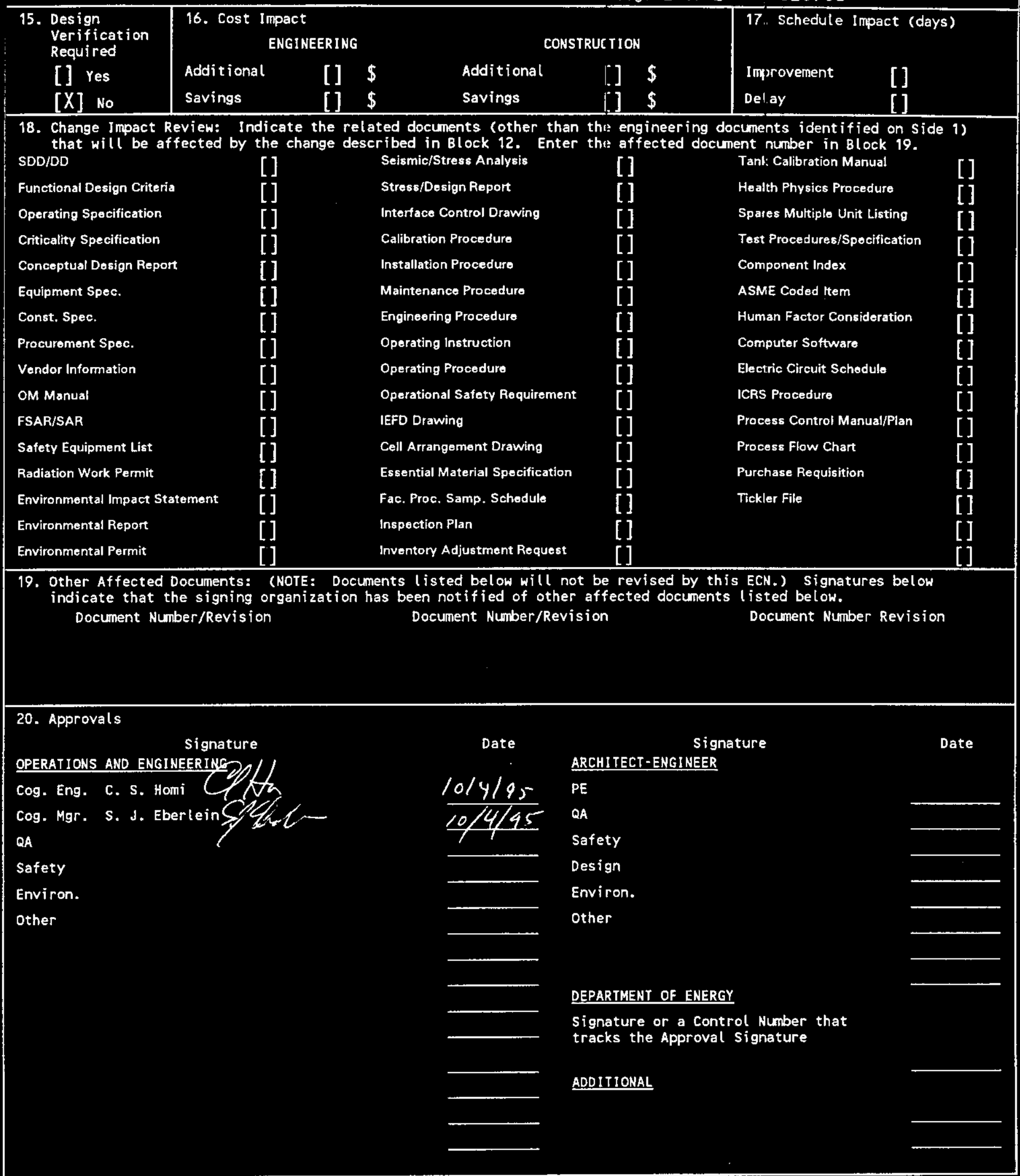




\section{RELEASE AUTHORIZATION}

Document Number: WHC-SD-WM-TP-275, REV 1

Document Title: Tank 241-BY-108 Tank Characterization Plan

Release Date: $\quad 10 / 4 / 95$

This document was reviewed following the procedures described in WHC-CM-3-4 and is:

APPROVED FOR PUBLIC RELEASE

WHC Information Release Administration Specialist:
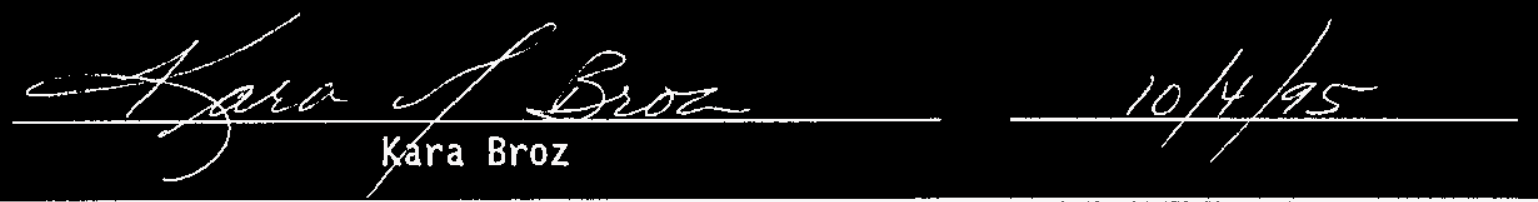

TRADEMARK DISCLAIMER. Reference here in to any specific commercial product, process, or service by trade name, trademark, manufacturer, or otherwise, does not necessarily constitute or imply its endorsement, recommendation, or favoring by the United States Government or any agency thereof or its contractors or subcontractors.

This report has been reproduced from the best available copy. Available in paper copy. Printed in the United States of America. To obtain copies of this report, contact:

Westinghouse Hanford Company - Document Control Services

P.0. Box 1970, Mailstop H6-08, Richland, WA 99352

Telephone: (509) 372-2420; Fax: (509) 376-4989 


\begin{tabular}{|l|l|c|}
\hline $\begin{array}{l}\text { 2. Title } \\
\text { TANK 241-BY-108 TANK CHARACTERIZATION PLAN }\end{array}$ & $\begin{array}{l}\text { 3. Number } \\
\text { WHC-SD-WM-TP-275 }\end{array}$ & 1 \\
\hline $\begin{array}{l}\text { 5. Key Hords } \\
\text { CHARACTERIZATION, GENERAL SAFETY ISSUES, SPECIFIC } \\
\text { SAFETY ISSUES, INFORMATION REQUIREMENTS, PRIORITY }\end{array}$ & $\begin{array}{l}\text { N. Author } \\
\text { Signature }\end{array}$ \\
& organization/Charge Code $75320 / \mathrm{N} 4 \mathrm{G} 6 \mathrm{~A}$ \\
\hline
\end{tabular}

\section{Abstract}

This document is a plan that identifies the information needed to address relevant issues concerning short-term and long-term safe storage and long-term management of Single-She11 Tank (SST) 241-BY-108.

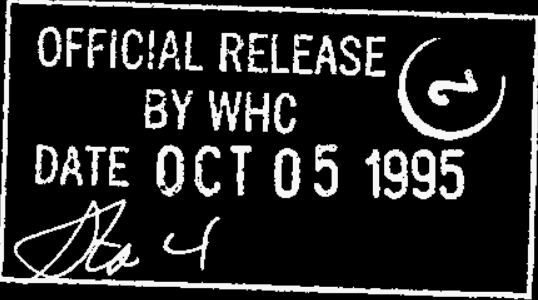




\section{RECORD OF REVISION}

(2) Title

TANK 241-BY-108 TANK CHARACTERIZATION PLAN

CHANGE CONTROL RECORD

\begin{tabular}{|c|c|c|c|}
\hline & 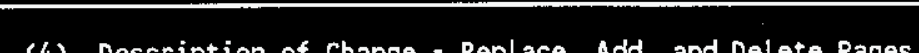 & Author & ied for Release \\
\hline (3) Revision & (4) Description of Change - Replace, Add, and Delete Pages & (5) Cog. Engr. & (6) Cog. Mgr. Date \\
\hline 0 & (7) WHC-SD-WM-TP-275, REV. 0, EDT 609586 & & \\
\hline$O A$ & Added Appendix B; ECN 617812 & & \\
\hline$O B$ & $\begin{array}{l}\text { Replaced pages A.1, A.2, A.6, A.11, A.12, } \\
\text { and A.13 of Appendix A. }\end{array}$ & & \\
\hline$O C$ & Added Appendix C; ECN 617837 & & \\
\hline RS 1 & Complete revision to new format, ECN 625708 & QPte & Selber ify/4: \\
\hline & & & \\
\hline & & & \\
\hline & & & \\
\hline & & & \\
\hline & & & \\
\hline & & & \\
\hline & & & \\
\hline & & & \\
\hline & & & \\
\hline & & & \\
\hline & & & \\
\hline & & & \\
\hline & & & \\
\hline & & & \\
\hline & & & \\
\hline & & & \\
\hline & & & \\
\hline & & & \\
\hline & & & \\
\hline & & & \\
\hline & & & \\
\hline & & & \\
\hline & & & \\
\hline
\end{tabular}




\title{
Tank 241-BY-108 Tank Characterization Plan
}

\author{
C. S. Homi \\ Westinghouse Hanford Company
}

\section{Date Published}

\section{October 1995}

Prepared for the U.S. Department of Energy Office of Environmental Restoration and Waste Management

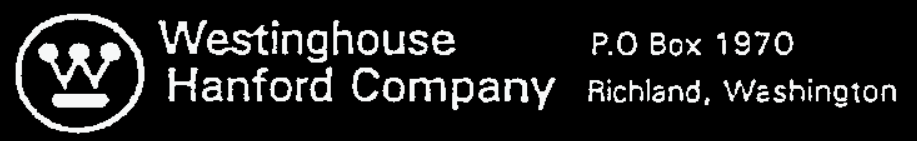


WHC-SD-WM-TP-275, REV 1

\section{TABLE OF CONTENTS}

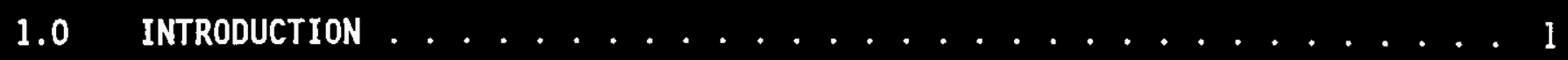

2.0 PROGRAM ELEMENTS REQUIRING INFORMATION FOR $241-$ BY-108 . . . . . . 2

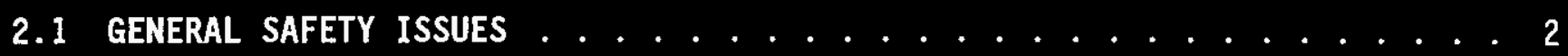

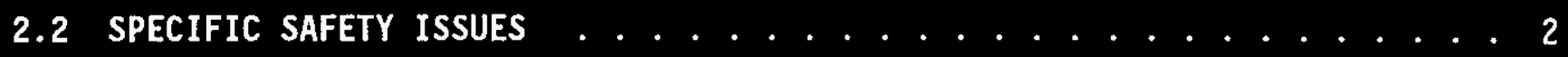

2.2.1 Ferrocyanide . . . . . . . . . . . . . . . . . . 2

2.2.2 Organic .......................... 2

2.2.3 High Heat ............................ 2

2.2.4 Flammable Gas . . . . . . . . . . . . . . . . . . . 2

2.2 .5 Vapor .............................. 3

2.2 .6 Criticality . . . . . . . . . . . . . . . . . . . 3

2.2.7 Screening Approach Evaluation . . . . . . . . . . . . . . . 3

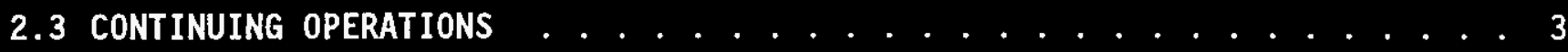

2.2.1 Compatibility/Stabilization . . . . . . . . . . . . . . 3

2.2.2 Evaporator ........................... 3

2.4 DOUBLE-SHELL TANK WASTE ANALYSIS PLAN . . . . . . . . . . 3

2.5 DISPOSAL . . . . . . . . . . . . . . . 3

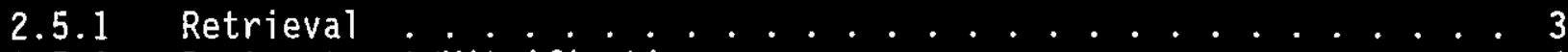

2.5.2 Pretreatment/Vitrification .......... 4

2.6 HISTORICAL MODEL EVALUATION . . . . . . . . . . . . 4

3.0 HOW INFORMATION WILL BE OBTAINED .............. 4

4.0 PRIORITY OF INFORMATION REQUIREMENTS . . . . . . . . . . 5

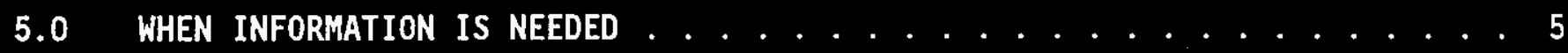

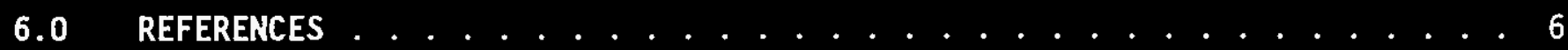

\section{LIST OF TABLES}

Table 4-1: Integrated DQO Requirements ........... 5 
WHC-SD-WM-TP-275, REV 1

\section{LIST OF ABBREVIATIONS}

$\begin{array}{ll}\text { BY-108 } & \text { Tank 241-BY-108 } \\ \text { DQ0 } & \text { Data Quality Objective } \\ \text { HTCE } & \text { Historical Tank Content Estimate } \\ \text { DSSF } & \text { Double She11 Slurry Feed } \\ \text { NCPLX } & \text { Non-complexed } \\ \text { SST } & \text { Single-Shell Tank } \\ \text { SUMMA } & \text { Trademark of Molectrics, Inc. } \\ \text { TCP } & \text { Tank Characterization P1an } \\ \text { TOC } & \text { Total Organic Carbon } \\ \text { USQ } & \text { Unreviewed Safety Question } \\ \text { WHC } & \text { Westinghouse Hanford Company }\end{array}$




\section{WHC-SD-WM-TP-275, REV 1}

\subsection{INTRODUCTION}

This Tank Characterization Plan (TCP) identifies the information needed to address relevant issues concerning short-term and long-term safe storage and long-term management of Single-She11 Tank (SST) 241-BY-108 (BY-108). It should be understood that the various needs and issues surrounding tank BY-108 are evolving as new information about the tank is uncovered. As a result of this progression, this Tank Characterization plan addresses only the issues that, to this date, have been identified. It is expected that deviations from this plan may occur as additional issues or needs arise which impact the management of SST BY-108. As necessary, this Tank Characterization $\mathrm{Plan}$ will be revised to reflect those changes or deviations.

Tank BY-108 was constructed between 1948 and 1949 and was put into service in April 1951. Initially tank BY-108 received first cycle waste from the tank 241-BY-107 cascade from the first quarter of 1951 until the second quarter of 1953 . The tank received U plant waste from the second quarter of 1953 until the first quarter of 1959. The tank became a ferrocyanide waste receiver in 1954 and the tank received in-plant ferrocyanide waste from the fourth quarter of 1954 until the first quarter of 1957. Various transfers out of the tank went to a ditch or a crib. From the second quarter of 1959 until the first quarter of 1968, the tank contained $U$ plant waste and coating waste. Between the second quarter of 1968 and the second quarter of 1973, the tank received evaporator bottoms waste. The evaporator bottoms waste was from the in-tank solidification process. From the third quarter of 1972 until the fourth quarter of 1975, the tank received wastewater. Presently, the tank waste is classified as non-complexed. This tank currently contains a total waste volume of $863.1 \mathrm{~kL}$ (228 $\mathrm{kgal}$ ), which is equivalent to 229.51 centimeters (90.36 inches) of waste as measured from the baseline of the tank. The waste is comprised of $238.5 \mathrm{~kL}(63 \mathrm{kgal})$ of saltcake; $624.6 \mathrm{~kL}(165 \mathrm{kgal})$ of sludge with no supernatant and pumpable liquid remaining (Brevick 1994a).

The tank is an assumed leaker (with a leak approximately greater than $18.9 \mathrm{~kL}$ (5 kgal) in 1973) and was labeled out of service in 1972. Tank BY-108 is passively ventilated, was partially isolated in December 1982 and was interim stabilized in February 1985. The last solids volume update was obtained on April 28, 1982 and the last photo was taken on October 15, 1986. The 1986 photographic montage shows a white waste surface (Brevick et al 1994).

There is no record of historical sampling and analys is information for tank BY-108. This tank is on the Ferrocyanide Watch list. The tank has an Unreviewed Safety Question (USQ) because of the potential consequences of a radiological release resulting from the ignition of the ferrocyanide constituents. Near-term sampling and analysis activities are focused on either verification of the watchlist tank status, identification of any new safety issues, changing the Watch List status, or resolving the USQ. Should any safety issues be identified additional analysis will occur consistent with the identified issue.

In addition to the resolution of the safety issues, it is intended that all tank waste will be subject to pretreatment and retrieval to prepare for final storage or disposal. Presently, these long-range plans have yet to be fully identified and are, therefore, not included in this document. 


\subsection{PROGRAM ELEMENTS REQUIRING INFORMATION FOR TANK 241-BY-108}

This section identifies the various program elements, and identifies which of these programs require characterization data from tank BY-108.

\subsection{GENERAL SAFETY ISSUES}

The Tank Safety Screening Data Quality Objective (Babad et a1. 1995a) describes the sampling and analytical requirements that are used to screen waste tanks for unidentified safety issues. The primary analytical requirements for the safety screening of a tank are energetics, total alpha activity, moisture content, and flammable gas concentration.

\subsection{SPECIFIC SAFETY ISSUES}

\subsubsection{Ferrocyanide}

This tank is on the Ferrocyanide Watch List. Sampling and analysis requirements must be performed as per Data Requirements for the Ferrocyanide Safety Issue Developed through the Data Quality Objectives Process (Meacham 1995). The analyses employed wil1 determine the total fuel concentration and moisture content. Total fuel concentration and moisture content are the primary data requirements. Also, further analyses will be employed to obtain secondary data such as temperature (data will be obtained from tank thermocouple(s)), nickel, total cyanide, TOC, ${ }^{137} \mathrm{Cs}$ and ${ }^{90} \mathrm{Sr}$ (Meacham 1994).

\subsubsection{Organic}

This tank is not on the Organics Watch List but, it has been decided to analyze the tank waste for this concern. Sampling and analys is requirements must be performed as per Data Quality Objective to Support Resolution of the Organic Fuel Rich Tank Safety Issue (Babad et al 1995b). The analyses employed will determine the TOC, presence of a free organic liquid phase, moisture content and tank temperature.

\subsubsection{High Heat}

This tank is not on the High Heat Watch List; therefore, no information needs are currently identified for this program element.

\subsubsection{Flammable Gas}

This tank is not on the Flammable Gas Watch List; therefore, no information needs are currently identified for this program element.

\subsubsection{Vapor}

The tanks currently scheduled to be vapor sampled may be classified into four categories: (1) those tanks which are to be rotary mode core sampled (as a consequence of the rotary sampling system); (2) tanks on the Organic or Ferrocyanide Watch Lists; (3) tanks in C farm; and (4) tank BX-104, due to vapor exposure. Since tank BY-108 is categorized in one of the above four groups, information needs must satisfy Data Quality Objectives for Generic In-Tank Health and Safety Vapor Issue Resolution (Osborne et al. 1995) and Rotary Sampling Core Vapor Sampling Data Quality Objective (Price 1994). Characterization of the tank headspace is needed to: 1) identify those tanks which can be sampled safely with intrusive equipment without risk of gas ignition; 2) identify and estimate concentrations of toxicologically significant 
compounds present in the tank headspace to establish worker safety precautions; and 3 ) support the startup and operation of the portable exhauster used during rotary-mode core sampling.

\subsubsection{Criticality}

No information separate from that for the general safety issue of tank BY-108 are currently identified for this program element. However, if the general safety screening of tank BY-108 identifies a potential criticality concern, analyses for fissile materials and neutron absorbers and poisons will be performed as identified in the safety screening data quality objective.

\subsubsection{Screening Approach Evaluation}

The safety screening approach is currently under review. Information is required from key tanks to determine if a revised approach to screening may be adopted, as proposed in Meacham, 1995.

\subsection{CONTINUING OPERATIONS}

\subsubsection{Compatibility/Stabilization}

No information needs are currently identified for this program element.

\subsubsection{Evaporator}

No information needs are currently identified for this program element.

\subsection{DOUBLE-SHELL TANK WASTE ANALYSIS PLAN}

This section does not apply because tank BY-108 is a single shell tank.

\subsection{DISPOSAL}

\subsubsection{Retrieval}

Current retrieval needs (Bloom 1995) do not call for test samples to be taken from tank BY-108.

\subsubsection{Pretreatment/Vitrification}

Tank BY-108 has been identified as a bounding tank for pretreatment/disposal process development (Kupfer 1995).

\subsection{HISTORICAL MODEL EVALUATION}

Bounding tanks and data requirements for historical model evaluations are found in DQO Historical Model Evaluation Data Requirements (Simpson 1995). Tank BY-108 has been identified as an alternate bounding tank for the PFeCN1 (ferrocyanide) waste type, but will not be assessed against the historical DQO unless directed by the program. 


\subsection{HOW INFORMATION WILL BE OBTAINED}

The safety screening $D Q 0$ requires that a vertical profile of the tank waste be obtained from at least two widely spaced risers. This vertical profile may be obtained using core, auger (for shallow tanks), or grab samples. Several sampling events of tank BY-108 are scheduled: one vapor sampling event and a rotary sampling event. No other sampling is scheduled through fiscal year 1996 (Stanton 1995). The rotary mode sampling type has been chosen over other sampling modes due to both the depth of the tank (making auger sampling inadequate) and the fact that the surface of tank BY-108 is comprised of saltcake (which is not conducive to good push mode core sampling recovery). Prior to rotary sampling it is necessary to vapor sample the tank as per requirements of Rotary Core Vapor Sampling Data Quality Objective (Price 1994).

The best current estimate of the water content in tank BY-108 solids, as determined from the process records, is $45.8 \%$; based on the HTCE (Brevick et al). Estimates (Toth et al 1995) of water content in tank BY-108 saltcake and sludge are $16.9 \%$ and $37.9 \%$ respectively (generated from a model based on sample data from similar tanks). The TOC contained with in the saltcake and sludge are estimated (Toth et al 1995) to be $0.7 \%$ and $0.1 \%$ (wet basis) respectively, which is significantly lower than the level of concern. Two core samples will be requested for this tank. If the true concentration of water is near the $17 \%$ action limit, it may not be possible to demonstrate through core samples that it is above the action limit.

The best current information indicates that 2 risers are available for sampling of tank BY-108, 12" $(30.5 \mathrm{~cm})$ riser R12A and $4^{\prime \prime}(10.2 \mathrm{~cm})$ riser R5. It is recommended that these risers be chosen because, they are risers that are separated radially and; therefore, will provide a larger amount of data about the vertical and horizontal waste layers within the tank. Initial information will be taken from these 2 risers and assessed to determine if more samples are required. Two additional riser are available, but equipment will have to be removed from one of these risers to utilize it for sampling. Alternate sampling methods, installation of a riser or removal of equipment from risers presently considered unavailable, are possible future options. 
WHC-SD-WM-TP-275, REV 1

\subsection{PRIORITY OF INFORMATION REQUIREMENTS}

Characterization of flammable and toxic vapors is a high priority for this tank. Vapor sampling was completed in October 1994 (Stanton 1995). Auger sampling was completed in December 1994. Rotary mode sampling was completed in July 1995 (Stanton 1995).

Table 4-1: Integrated DQO Requirements

\begin{tabular}{|c|c|c|c|}
\hline Sampling & Appi icable 000 & Samp I ing Requirements & Anal to ical Requirements \\
\hline $\begin{array}{l}\text { Vapor } \\
\text { Sampling }\end{array}$ & $\begin{array}{l}\text { - Health \& Safety Vapor } \\
\text { Issue Resolution DQO } \\
\text { - Rotary Sampl ing Core } \\
\text { Vapor Sampling DQO }\end{array}$ & $\begin{array}{l}3 \text { SUMMA® canisters } \\
12 \text { Triple Sorbent Traps } \\
6 \text { Sorbent Trap Systems }\end{array}$ & $\begin{array}{l}\text { Gas Flammability } \\
\text { Gas Toxicity } \\
\text {-Organic Vapors } \\
\text {-Permanent Gases }\end{array}$ \\
\hline $\begin{array}{l}\text { Rotary } \\
\text { Core and } \\
\text { Auger } \\
\text { Sampling }\end{array}$ & $\begin{array}{l}\text {-Safety Screening DQO } \\
\text {-Ferrocyanide DQO } \\
\text {-Organic Fue1-Rich DQO } \\
\text {-Pretreatment DQO }\end{array}$ & $\begin{array}{l}\text { Core samples from } 2 \\
\text { risers separated } \\
\text { radially to the maximum } \\
\text { extent possible }\end{array}$ & $\begin{array}{l}\text { Energetics, Moisture, } \\
\text { Total Alpha, SpG, Total } \\
\text { Organic Carbon, Ni, CN }\end{array}$ \\
\hline
\end{tabular}

\subsection{PRIORITY OF INFORMATION REQUIREMENTS}

Data are required for Tank BY-108 during FY 1996 for safety screening and to prepare a Tank Characterization Report. 


\subsection{REFERENCES}

Babad, H, K. S. Redus, and J. W. Hunt, 1995a, Tank Safety Screening Data Quality Objective, WHC-SD-WM-SP-004, Rev 1, Westinghouse Hanford Company, Richland, Washington.

Babad, H., S. M. Blacker, and K. S. Redus, 1995b, Data Quality Objective to Support Resolution of the Organic Fuel Rich Tank Safety Issue, WHC-SD-WM-0Q0-006, Rev. 1, Westinghouse Hanford Company, Richland, Washington.

Bloom, G. R., and Q. H. Nguyen, 1995, Characterization Data Needs for Development, Design, and Operation of Retrieval Equipment Developed Through the Data Quality Objective Process, WHC-SD-WM-DQ0-008, Rev. 0, Westinghouse Hanford Company, Richland, Washington.

Brevick, C. H., 1994a, Historical Tank Content Estimate for the Northeast Quadrant of the Hanford 200 East Areas, WHC-SD-WM-ER-349, Rev. Oa, ICF Kaiser Hanford Company, Richland, Washington.

Brevick, C. H., 1994b, Supporting Document for the Historical Tank Content Estimate for BY Tank Farm, WHC-SD-WM-ER-312, Rev. 0, ICF Kaiser Hanford Company, Richland, Washington.

Brown, T. M., S. J. Eberlein, D. A. Dodd, T. J. Kunthara, B. C. Simpson, and N. W. Kirch, Tank Waste Characterization Plan and Basis, 1995, WHC-SD-WM-TA-164, Rev 0, Westinghouse Hanford Company, Richland, Washington.

Fowler, K.D., 1995, Data Quality Objectives for the Waste Compatibility Program, WHC-SD-WM-DQO-001, Rev. 1, April 1995, Westinghouse Hanford Company, Richland, Washington.

Hanlon, B.M., 1995, Waste Tank Summary for Month Ending May, 1995, WHC-EP-0182-82, Westinghouse Hanford Company, Richland, Washington.

Homi, C. S., and S. J. Eberlein, 1995, Fiscal Year 1996 Tank Waste Remediation System Tank Waste Analysis Plan, WHC-SD-WM-PLN-101, Rev 0, Westinghouse Hanford Company, Richland, Washington

Kupfer, M. J., W. W. Schultz, and J. T. S1ankas, 1995, Strategy for Sampling Hanford Site Tank Wastes for Development of Disposal Technology, WHC-SD-WM-TA-154, Rev. 1, Westinghouse Hanford Company, Richland, Washington.

Meacham, J. E., R. J. Cash, B. A. Pulsipher, and G. Chen, 1995, Data Requirements for the Ferrocyanide Safety Issue Developed through the Data Quality Objectives Process, WHC-SD-WM-DQ0-007, Rev. 1, Westinghouse Hanford Company, Richland, Washington.

Osborne, J.W., J.L. Huckaby, E.R. Hewitt, C.M. Anderson, D.D. Mahlum, B.A. Pulsipher, and J.Y. Young, 1995, Data Quality Objectives for Generic In-Tank Health and Safety Vapor Issue Resolution, WHC-SD-WM-DQ0-002, Rev. 1, Westinghouse Hanford Company, Richland, Washington.

Price, D. N., 1994, Rotary Core Vapor Sampling Data Quality Objective, WHC-SD-WM-SP-003, Rev. 0, Westinghouse Hanford Company, Richland, Washington.

Simpson, B. C., and D. J. McCain, 1995, Historical Model Evaluation Data Requirements, 


\section{WHC-SD-WM-TP-275, REV 1}

WHC-SD-WM-DQ0-018, Rev. 0, Westinghouse Hanford Company, Richland, Washington.

Stanton, G. A., 1995, Baseline Sampling Schedule, Revision 4.3, (internal memo 74320-95-04, to distribution, March 24), Westinghouse Hanford Company, Richland, Washington.

Toth, J. J., P. G. Heasler, M. E. Lerchen, J. G. Hill, and P. D. Whitney, 1995, Analysis of Organic Carbon and Moisture in Hanford Single-Shell Tank Waste, PNL10360, Pacific Northwest Laboratory, Richland, Washington.

Webb, A. B., J. L. Stewart, D. A. Turner, M. G. P1ys, B. Malinovic, J. M. Grigsby, D. M. Camaioni, P. G. Heasler, W. D. Samuels, and J. J. Toth, 1995, Preliminary Safety Criteria for Organic Watch List Tanks at the Hanford Site, WHC-SD-SARR-033, Rev. 0, Draft, Westinghouse Hanford Company, Richland, Washington. 